\title{
Profil Kesalahan Mahasiswa PGSD dalam Menyelesaikan Soal Cerita pada Mata Kuliah Pembelajaran Matematika SD
}

\author{
Rusdyi Habsyi \\ Program Studi Pendidikan Matematika, STKIP Kie Raha, Indonesia \\ *Coresponding Author: rusdy.habsy@gmail.com
}

\begin{tabular}{ll}
\hline \hline Article history & Penelitian ini merupakan penelitian Deskriptif yang bertujuan \\
Dikirim: & untuk. (1) mengidentifikasi jenis-jenis kesalahan yang dilakukan \\
& oleh mahasiswa PGSD dalam menyelesaikan soal cerita pada \\
Direvisi: & Mata Kuliah Pembelajaran Matematika SD; (2). Mengidentifikasi \\
10-12-2021 & jenis kesalahan yang paling banyak dilakukan oleh mahasiswa \\
& PGSD dalam menyelesaikan soal cerita pada Mata Kuliah \\
Diterima: & Pembelajaran Matematikan SD. Subjek penelitian ini adalah \\
$11-12-2021$ & mahasiswa Semeter V PGSD Tahun akademik 2020/2021 \\
& sebanyak 37 mahasiswa. Pengambilan data dilakukan dengan \\
Key words: & menggunakan instrument yaitu tes diagnostik. Hasil analisis \\
\hline Profil Kesalahan & statistik deskriptif adalah deskripsi mengenai jumlah kesalahan \\
mahasiswa; Soal Cerita; & yang banyak dilakukan mahasiswa adalah 2 dengan persentase \\
Pembelajaran matematika & 37,8\%, banyaknya mahasiswa yang melakukan kesalahan dengan \\
SD & jumlah tersebut adalah 14 mahasiswa dan persentase kesalahan \\
& penyelesaian soal cerita untuk jenis kesalahan pada tiap item. \\
& Item 1, kesalahan teknis 13,51\%; item 2, kesalahan algoritma \\
& $16,21 \%$; item 3, kesalahan konsep dan algoritma 29,72\%; item 4, \\
& kesalahan algoritma 21,62 \%; item 5, Kesalahan konsep 37,83\%. \\
\hline \hline
\end{tabular}

\section{PENDAHULUAN}

Pada masa sekarang ini kebutuhan akan pendidikan merupakan kebutuhan pokok yang sangat mutlak diperlukan oleh semua lapisan masyaraka. Salah satu faktor yang sangat menentukan kemajuan suatu bangsa adalah penguasaan terhadap ilmu dan teknologi. Dalam era perkembangan ilmu dan teknologi yang semakin pesat, maka tumpuan potensi tidak lagi pada potensi sumber daya alam, tetapi bergeser pada .potensi sumber daya manusia. Oleh karena itu, dalam dinamika pembangunan nasional sangat diperlukan dalam upaya peningkatan kualitas sumber daya manusia. Pembangunan di segala bidang akan berhasil dengan baik bila didukung oleh sumber daya manusia yang berkualitas tinggi.

Pendidikan memegang peranan penting dan strategis dalam upaya npeningkatan kualitas sumber daya. Karena pendidikan merupakan salah satu wadah untuk menciptakan sumber daya manusia yang berkualitas.

Melalui pendidikan akan ditumbuhkan manusia yang mempunyai nketerampilan dan kemampuan yang tinggi. Oleh karena itu, pendidikan harus mendapat perhatian yang serius dan sungguh-sungguh, baik pendidikan formal maupun pendidikan non formal.

Perkembangan ilmu pengetahuan memungkinkan semua pihak dapat memperoleh informasi dengan mudah dan cepat dari berbagai sumber dan tempat di dunia. Dengan demikian, mahasiswa perlu memiliki kemampuan memperoleh, memilih dan mengelola informasi untuk bertahan pada keadaan yang selalu 
berubah, tidak pasti, dan kompetitif. Kemampuan ini membutuhkan pemikiran kritis, sistematis, logis, kreatif dan kemampuan bekerjasama yang efektif. Cara berfikir seperti ini dapat dikembangkan melalui belajar matematika karena matematika memiliki struktur dan keterkaitan yang kuat dan jelas konsepnya, sehingga memungkinkan mahasiswa terampil berpikir rasional.

Pendidikan matematika yang diajarkan pada pendidikan formal merupakan pendidikan yang sangat mendasar dan diperlukan guna menumbuhkembangkan kemampuan dan membentuk pribadi mahasiswa serta berpedoman kepada perkembangan IPTEK. Realisasi pentingnya pelajaran matematika diajarkan pada peserta didik, tercermin dengan ditempatkannya matematika sebagai ilmu dasar bagi semua jenis tingkat pendidikan.

Tujuan npembelajaran matematika adalah (Masrura, 2005).

1. Melatih cara berpikir dan bernalar dalam menarik kesimpulan, misalnya melalui kegiatan penyelidikan, eksplorasi, eksperimen, menunjukkan kesamaan, perbedaan, dan konsistensi.

2. Mengembangkan aktivitas kreatif yang melibatkan imajinasi, intuisi dan penemuan dengan mengembangkan pemikiran divergen, orisinil, rasa ingin tahu membuat prediksi dan dugaan, serta mencoba-coba

3. Mengembangkan kemampuan memecahkan masalah

4. Mengembangkan kemampuan dengan menyampaikan informasi atau mengkomunikasikan gagasan antara lain melalui pembicaraan lisan, grafik, peta dan diagram.

Mengingat pentingnya peranan matematika maka sangatlah diharapkan agar mahasiswa menguasai mata kuliah matematika sesuai dengan tuntutan kurikulum.

Berbagai usaha yang telah dilakukan dalam rangka peningkatan prestasi belajar matematika. Salah satu hal yang perlu diperhatikan berkaitan dengan usaha peningkatan prestasi belajar matematika adalah dengan memperhatikan hasil-hasil yang telah dicapai. Misalnya dalam hal kemampuan menyelesaikan masalah matematika sesuai dengan yang diharapkan. Dengan demikian dapat diambil langkah-langkah dalam usaha penanaman dan peningkatan kemampuan tersebut, seperti peningkatan proses, peningkatan sarana dan prasarana.

Salah satu kemampuan penting dan diharapkan dikuasai oleh mahasiswa adalah kemampuan menyelesaikan soal cerita matematika dengan benar karena soal cerita dalam matematika lebih mendekatkan masalah matematika ke dalam dunia nyata. Pada umumnya mahasiswa lebih tertarik menyelesaikan masalah matematika dalam bentuk soal cerita. Akan tetapi dalam menyelesaikan soal-soal terkadang mahasiswa mengalami kesulitan. Dalam hal ini kesulitan yang dimaksud adalah seringnya mahasiswa melakukan kesalahan-kesalahan saat menyelesaikan soal cerita. Berdasarkan hasil pengamatan peneliti sewaktu mengampu mata kuliah pembelajaran matematika SD, salah satu bentuk kesalahan yang terjadi pada mahasiswa saat menyelesaikan soal khususnya pada soal cerita antara lain: kesalahan dalam merancang model matematika dari soal yang diberikan. Hal ini biasanya terjadi secara berulang-ulang, walaupun telah diberi arahan mengenai maksud dari soal yang diberikan.

Atas dasar pemikiran diatas, untuk mengetahui kesalahan-kesalahan yang mungkin dilakukan oleh mahasiswa PGSD STKIP Kie Raha semester V dalam menyelesaikan soal cerita pada mata kuliah pembelajaran matematika SD. Penulis 
terdorong untuk melakukan penelitian yang berjudul Profil Kesalahan Mahasiswa dalam Menyelesaikan Soal Cerita pada Mata Kuliah Pembelajaran Matematika $S D$.

Dalam penelitian ini diidentifikasi lima jenis kesalahan yaitu: 1). Kesalahan Konsep; 2). Kesalahan Menggunakan data; 3). Kesalahan Interpretasi bahasa; 4). Kesalahan Algoritma; 5). Kesalahan Teknis.

Sedangkan rumusan masalah dalam penelitian ini sebagai berikut:

1. Menentukan jenis-jenis dan besarnya kesalahan yang dilakukan oleh mahasiswa dalam menyelesaikan soal cerita pada mata kuliah pembelajaran matematika SD.

2. Mengidentifikasi Jenis kesalahan yang paling banyak dilakukan mahasiswa dalam nmenyelesaikan soal cerita pada mata kuliah pembelajaran matematika SD.

\section{KAJIAN TEORI}

\section{Soal Cerita Matematika}

Belajar matematika tidak terlepas dari bagaimana cara menyelesaikan soal cerita matematika, yang bertujuan untuk memperdalam penguasaan konsepkonsep matematika dan sekaligus sebagai latihan mengaplikasikan dalam penyelesaian masalah. Manfaat belajar matematika akan terasa bila mahasiswa diberikan soal-soal yang menggambarkan masalah nyata dalam kehidupan seharihari, yang pemecahannya menggunakan matematika (Sirajuddin, 2005) . Soal semacam ini dinamakan soal cerita matematika yang isinya banyak menggambarkan permasalahan sehari-hari. Proses penyelesaian soal cerita merupakan proses mental yang kompleks dalam diri mahasiswa.

Pemecahan soal cerita matematika memerlukan keterampilan nmenghitung, membaca, dan kemampuan menyatakan hubungan, serta pemecahan soal cerita memerlukan prosedur analisa serta langkah-langkah sebagai berikut:

a. Memahami soal dengan mengetahui informasi yang diberikan, yang harus dicari, arti kata-kata atau istilah yang ada dari soal yang sejenis yang pernah diberikan.

b. Menentukan hubungan yang ada dengan soal yang pernah diselesaikan serta membuat soal yang lebih sederhana.

c. Menentukan strategi dan mengidentifikasi struktur soal (fakta-fakta, syaratsyarat yang ada) kemungkinan menentukan model penyelesaian.

d. Meng gunakan model yang telah ditentukan

e. Menafsirkan hasil yang diperoleh

f. Menganalisis metode penyelesaian, yaitu melukiskan langkah-langkah dalam urutan logis, menunjukkan informasi yang diperoleh, dan penalaran yang digunakan

Adapun menurut Team Matematika Depdikbud setiap soal cerita dapat diselesaikan dengan rencana:

a. Membaca soal itu dan memikirkan hubungan antara bilangan yang terdapat dalam soal.

b. Menuliskan kalimat matematika tersebut, menentukan bilangan-bilangan yang memenuhi agar kalimat tersebut menjadi benar. 
c. Menyelesaikan kalimat matematika tersebut, menentukan bilangan-bilangan yang memenuhi agar kalimat tersebut menjadi benar.

d. Menggambarkan penyelesaian itu untuk menjawab pertanyaan dalam soal.

\section{Model Matematika}

Dalam menyelesaikan soal cerita matematika salah satu langkah yang sangat penting adalah pembuatan model matematika. Model ini dapat dianggap sebagai usaha abstraksi terhadap objek lewat cara analisis dalam bentuk persamaanpersamaan matematika, dengan maksud untuk mendapatkan gambaran-gambaran yang jelas tentang suatu objek yang kita perhatikan (Hudoyo, 2004).

Dalam penyusunan model tidak ada istilah modelnya benar atau salah, yang ada adalah model itu baik atau jelek. Suatu model dikatakan baik bila mampu memberikan gambaran objeknya dengan cukup jelas sehingga penyusunan model tercapai. Model tidak sesuai bila tujuan penyusunan model tidak dapat sepenuhnya tercapai karena model terlalu jauh dari keadaan objek yang sesungguhnya.

Membuat model akan memudahkan dalam penyelesaian soal cerita matematika, karena fungsi suatu model adalah menirukan/menggambarkan semirip mungkin perilaku/keadaan objek yang diamati, sesuai dengan tujuan penyusunan model. berikut:

Adapun tujuan penyusunan model menurut Susanta (Wahid, 2003) sebagai

a. Untuk mengenali perilaku objek dengan cara mencari keterkaitan antara unsurunsurnya.

b. Untuk mengadakan pendugaan (prediksi) untuk memperbaiki keadaan objek.

c. Untuk mengadakan optimalisasi dalam objek.

\section{Menyelesaikan Soal Cerita Matematika}

Memecahkan suatu masalah merupakan suatu aktivitas manusia. Kita perlu mencari penyelesaiannya. Bila kita gagal dengan suatu cara untuk menyelesaikan suatu masalah, kita harus mencoba lagi menyelesaikan suatu masalah, kita harus mencoba lagi menyelesaikannya dengan cara lain. Nampak di sini bahwa memecahkan masalah itu merupakan aktivitas mental yang tinggi dan kompleks, yaitu melibatkan visualisasi, imajinasi, abstraksi, dan asosiasi informasi yang diberikan. Karena itu penyelesaian masalah melalui proses belajar mengajar matematika dapat membantu mahasiswa dalam meningkatkan dan mengembangkan kemampuannya pada aspek penerapan, analisis, sintesis, dan evaluasi.

Menurut Hudoyo (Wahid, 2003) menyatakan bahwa pertanyaan merupakan masalah bagi seseorang, bila orang itu tidak memiliki aturan hukum tertentu yang segera dapat digunakan untuk menentukan jawaban pertanyaan tersebut pertanyaan itu dapat juga terselinap dalam suatu situasi sedemikian sehingga situasi itu sendiri perlu mendapat penyelesaian.

Sedangkan menurut Muhkal (1999:4-5) menyatakan bahwa Suatu pertanyaan merupakan masalah, jika pertanyaan itu menyajikan suatu tantangan dan tidak dapat diselesaikan dengan cara-cara rutin. Selain itu, suatu pertanyaan yang menantang merupakan masalah bagi seseorang, bila orang itu menerima tantangan tersebut. ini berarti bila orang itu menerima tantangan tersebut, maka pernyataan itu bukan masalah baginya. 
Dari definisi di atas, dapat dikatakan bahwa suatu masalah merupakan suatu kondisi dimana seseorang membutuhkan sesuatu, tetapi ia tidak mengetahui langkah-langkah apakah yang dapat dilakukan untuk memecahkannya. Namun, pada dasarnya tidak ada langkah-langkah yang perlu ditempuh dalam menyelesaikan suatu masalah yang baku. Banyaknya langkah-langkah yang perlu ditempuh dalam menyelesaikan suatu masalah sangat tergantung dari tingkat kesukaran dan kemampuan yang dimiliki oleh orang yang menyelesaikan masalah dengan kesalahan yang minim atau dengan tidak melakukan kesalahan dalam menyelesaikan soal, namun demikian terdapat banyak teknik atau strategi penyelesaian masalah yang dikemukakan oleh para ahli yang dapat dijadikan kerangka acuan.

George Polya (Rohani, 2000) mengemukakan suatu teknik penyelesaian masalah matematika yang disebut teknik heuristies. Adapun langkah-langkah dalam teknik heuriestis sebagai berikut:

a. Pemahaman Soal

Untuk memahami persoalan perlu dijawab meliputi:

- $\quad$ Menyatakan dengan rinci dan eksplisit

- $\quad$ Apa yang diketahui

- $\quad$ Apa yang ditanyakan

- $\quad$ Apa syarat-syarat yang harus dipenuhi

b. Pemikiran Suatu Rencana Penyelesaian

Yang penting untuk dipikirkan dalam suatu rencana penyelesaian, yaitu:

- Mencari hubungan antara apa yang ditanyakan dengan apa yang diketahui

- Apakah pernah menemui masalah serupa

- Apakah masalah yang pernah dilihat ada kaitannya dengan masalah tersebut

c. Pelaksanaan Rencana Penyelesaian

Dalam pelaksanaan rencana penyelesaian, meliputi:

- Memeriksa atau meneliti setiap langkah

- Apakah setiap langkah yang dilakukan sudah benar

- Apakah langkah yang benar dapat diajukan benarnya

d. Peninjauan Kembali

Dalam peninjauan kembali, meliputi:

- Mengoreksi hasil pendapatan yang diperoleh

- Dapatkah hasil tersebut atau metode itu digunakan untuk soal lain

Berdasarkan proses penyelesaian masalah yang dikemukakan di atas, Dalam Penyelesaikan soal cerita matematika terkadang mahasiswa melakukan kesalahan, yaitu: Kesalahan Konsep, Kesalahan Menggunakan data, Kesalahan Interpretasi bahasa, Kesalahan Algoritma, dan Kesalahan Teknis

Dalam penelitian ini, kesalahan yang disebutkan di atas merupakan kesalahan yang kerap kali dilakukan oleh mahasiswa.

\section{Kesalahan dalam Menyelesaikan Soal Cerita Matematika}

Kesalahan dalam menyelesaikan soal cerita matematika merupakan penyimpangan terhadap hal yang benar yang sifatnya sistematis, konsisten, maupun insedentil, yang sifatnya sistematis dan konsisten disebabkan oleh rendahnya frekuensi belajar peserta didik.

Menurut Hudoyo (1992: 7) dalam menyelesaikan masalah matematika, permasalahan dimodifikasi sebagai berikut: 
1) Mengerti masalah

2) Merencanakan penyelesaian

3) Melaksanakan penyelesaian

4) Mendapatkan penyelesaikan

Dalam nmenyelesaikan persoalann nmatematika nmahasiswa nbiasanya melakukan nkesalahan-kesalahan tersebut dibagi atas lima jenis yaitu: (Masrura, 2005).

\section{a. Kesalahan Konsep}

Konsep dalam matematika adalah suatu ide abstrak yang mengakibatkan seseorang dapat mengklasifikasikan objek-objek atau kejadian dan menentukan apakah objek atau kejadian itu merupakan contoh atau bukan contoh dari ide tersebut. Berkaitan dengan itu, Hudoyo (1992) menyatakan bahwa belajar konsep adalah belajar memahami sifat-sifat dari benda-benda konkrit atau peristiwaperistiwa untuk dikelompokkan satu jenis.

Pada dasarnya konsep matematika adalah ide abstrak tentang klasifikasi objek-objek atau kejadian-kejadian. Seseorang yang mengerti konsep akan mampu menentukan apakah objek-objek atau kejadian-kejadian merupakan contoh atau bukan contoh dari ide abstrak yang dimaksud.

Kesalahan konsep dalam matematika akan berakibat lemahnya penguasaan materi secara utuh apalagi kesalahan pada konsep dasar akan menyulitkan penguasaan konsep selanjutnya yang lebih tinggi. Hal ini mengingat urutan materi pelajaran matematika tersusun secara hirarki, konsep yang satu menjadi dasar untuk memahami konsep yang lain.

\section{b. Kesalahan nMenggunakan Data}

Dalam menyelesaikan masalah matematika, menurut Sirajuddin (2005) "data merupakan hal yang paling penting untuk diperhatikan karena sering terjadi kekeliruan dalam menggunakan data“. Dalam menyelesaikan soal matematika, meskipun rumus telah tersedia tetapi terjadi kekeliruan dalam menggunakan data maka akan diperoleh jawaban yang salah. Misalnya memuat data yang seharusnya tidak digunakan atau memasukkan data ke dalam rumus secara keliru.

\section{c. Kesalahan Interpretasi Bahasa}

Bahasa matematika merupakan bahasa simbolis karena itu npepmahaman terhadap simbol-simbol tersebut merupakan prasyarat utama untuk dapat memahami bahasa matematika. Persoalan matematika biasanya disajikan dalam bentuk soal cerita, diagram, tabel dan sebagainya. Semuanya itu mempunyai arti dan akan menjadi jelas apabila dapat diinterpretasikan dengan benar. Proses penyelesaian soal cerita matematika merupakan proses mental yang kompleks dalam diri mahasiswa. menurut Marjono (1984: 6-7), pemecahan soal cerita matematika memerlukan keterampilan menghitung, membaca, dan kemampuan menyatakan hubungan.

Untuk menyelesaikan persoalan matematika yang berbentuk suatu soal cerita maka terlebih dahulu harus mengubah soal cerita yang menggunakan bahasa sehari-hari menjadi kalimat matematika. Jika salah dalam mengartikan maka tidak mungkin memberikan solusi yang tepat. Dengan demikian kemampuan interpretasi bahasa yang menyangkut penguasaan bahasa dalam matematika sangat diperlukan dalam pemecahan soal matematika.

\section{d. Kesalahan Algoritma}


Algoritma merupakan rentetan logika yang diperlukan untuk melakukan suatu kegiatan, misalnya memecahkan suatu masalah. Pemecahan masalah algoritma juga menentukan kebenaran dari solusi pemecahan.

Adapun ciri-ciri dari algoritma menurut Chapra (Suhaemi, 2000: 17):

a. Tiap langkah harus dideterministik yaitu tidak ada yang tinggal untuk ditebak.

Hasil akhir tidak boleh tergantung pada siapa yang menjalankannya.

b. Suatu algoritma tidak boleh berakhir terbuka.

c. Algoritma harus cukup menangani keperluan apapun.

\section{e. Kesalahan Teknis}

Kesalahan teknis yang dimaksud pada masalah ini adalah kesalahan perhitungan atau perhitungan yang tidak tepat dan kesalahan memanipulasi operasi aljabar. Kecepatan dan ketepatan dalam menyelesaikan soal-soal matematika menunjukkan adanya kemampuan teknis yang baik.

Dalam menyelesaikan masalah matematika, meskipun telah mampu menentukan dan menggunakan rumus, mampu menggunakan data dan menggunakan algoritma yang tepat tapi jika melakukan kesalahan perhitungan atau kesalahan operasi aljabar, maka tetap akan memberikan solusi yang tidak tepat atau salah. (Kolins et al., 2020) menegaskan bahwa "dalam menyelesaikan masalah matematika diperlukan kegiatan mental yang tinggi sehingga dapat menemukan akal muslihat (trick) yang perlu diketahui. Jadi dalam menyelesaikan masalah matematika sangat diperlukan adanya kemampuan teknis, kecepatan dan ketepatan dalam menyelesaikan soal-soal matematika menunjukkan adanya kemampuan teknis yang baik.

\section{METODE PENELITIAN}

Penelitian ini merupakan penelitian deskriptif yang bertujuan untuk mendeskripsikan jenis-jenis kesalahan yang dilakukan mahasiswa dalam menyelesaikan soal cerita pada pokok bahasan persamaan kuadrat

Variabel yang teliti dalam penelitian ini adalah variabel tunggal yaitu kesalahan mahasiswa dalam menyelesaikan soal cerita persamaan kuadrat. Kesalahan mahasiswa meliputi: kesalahan interpretasi bahasa, kesalahan konsep, kesalahan menggunakan data, kesalahan Algoritma/prosedur, kesalahan teknis.

Kesalahan mahasiswa yang dimaksud dalam penelitian ini adalah kesalahan yang dibuat oleh mahasiswa dalam menyelesaikan pada mata kuliah pembelajaran matematika SDyang mencakup:

1. Kesalahan konsep (A), konsep yang dimaksud dalam penelitian ini adalah aturan yang berupa rumus pada mata kuliah pembelajaran matematika SDyang tidak diterapkan mahasiswa dalam penyelesaian soal, dengan sistem pengambilan data kesalahan mahasiswa yaitu jika mahasiswa mengalami kesalahan pada kategori ini maka kesalahan tersebut diberi tanda 1 dan jika benar diberi tanda 0 .

2. Kesalahan menggunakan data (B), data yang dimaksud dalam penelitian ini adalah keterangan atau bahan nyata yang dapat dijadikan dasar kajian dalam menyelesaikan masalah pada mata kuliah pembelajaran matematika SDnamun tidak diterapkan mahasiswa, dengan sistem pengambilan data kesalahan mahasiswa yaitu jika mahasiswa mengalami kesalahan pada kategori ini maka kesalahan tersebut diberi tanda 1 dan jika benar diberi tanda 0 . 
3. Kesalahan interpretasi bahasa (C), interpretasi bahasa yang dimaksud dalam penelitian ini adalah pendapat atau tafsiran terhadap bahasa yang digunakan dalam soal cerita pada mata kuliah pembelajaran matematika SDnamun tidak dapat diterapkan mahasiswa, dengan sistem pengambilan data kesalahan mahasiswa yaitu jika mahasiswa mengalami kesalahan pada kategori ini maka kesalahan tersebut diberi tanda 1 dan jika benar diberi tanda 0 .

4. Kesalahan algoritma (D), algoritma yang dimaksud dalam penelitian ini adalah prosedur sistematis yang disesuaikan dengan penekunan proses belajar mengajar mengikuti prosedur sesuai dengan yang ditekankan pada saat proses belajar mengajar dalam pokok bahasan pada mata kuliah pembelajaran matematika SDnamun tidak diterapkan mahasiswa, dengan sistem pengambilan data kesalahan mahasiswa yaitu jika mahasiswa mengalami kesalahan pada kategori ini maka kesalahan tersebut diberi tanda 1 dan jika benar diberi tanda 0 .

5. Kesalahan teknis (E), teknis yang dimaksud dalam penelitian ini adalah ketepatan operasi aljabar dan perhitungan dalam pada mata kuliah pembelajaran matematika SDnamun tidak diterapkan mahasiswa, dengan sistem pengambilan data kesalahan mahasiswa yaitu jika mahasiswa mengalami kesalahan pada kategori ini maka kesalahan tersebut diberi tanda 1 dan jika benar diberi tanda 0 .

Subjek dalam penelitian ini adalah mahasiswa PGSD Semeter V tahun pelajaran 2020/2021, yang jumlahnya 37 orang mahasiswa. Adapun alasan peneliti memilih kelas A. Selain peneliti mengampuh mata kuliah di kelas A, kelas A dan B adalah kelas yang homogen.

Untuk mengetahui profil kesalahan yang mungkin dilakukan oleh mahasiswa pada saat menyelesaikan soal cerita matematika yang juga secara langsung dapat diketahui kemampuan dalam penguasaan mahasiswa terhadap materi persamaan kuadrat, maka penulis membuat instrumen dalam bentuk tes essai dengan memperhatikan ruang lingkup pelajaran matematika berdasarkan kurikulum KKNI. Untuk mengetahui validitas instrumen yang digunakan maka dilakukan validasi oleh dosen validator serta dikonsultasikan dengan dosen matematika dari sekolah tempat penelitian. Setelah pelaksanaan tes selesai, dilakukan pemeriksaan terhadap jawaban mahasiswa. Jumlah kesalahan semua butir item didasarkan atas petunjuk yang telah disusun.

Metode yang digunakan adalah metode analisis yaitu menyiapkan model jawaban. Setelah model ini disusun, maka jawaban masing-masing responden dibandingkan dengan model tersebut dan diberi tanda 1 jika mahasiswa salah dan 0 jika mahasiswa benar sesuai dengan kesalahan yang dilakukan.

Adapun pengumpulan data yaitu:

1. Tahap persiapan

Langkah yang ditempuh dalam tahap ini adalah:

a. Pemeriksaan dan pemantapan akhir instrument yang digunakan

b. Menggandakan instrumen

2. Tahap Pengumpulan data

a. Peneliti menyampaikan beberapa penjelasan yang perlu kepada mahasiswa sehubungan dengan pelaksanaan dan maksud pemberian tes. 
b. Selama pengerjaan tes, pengawasan dilakukan sedemikian rupa sehingga memperkecil adanya kerjasama diantara mereka.

c. Setelah pengumpulan data selesai, diadakan pemeriksaan besarnya kesalahan mahasiswa dalam menyelesaikan soal cerita pada mata kuliah pembelajaran matematika SD dengan pemberian tanda 1 jika mahasiswa melakukan kesalahan dan tanda 0 jika tidak terdapat kesalahan.

Untuk unmemperolehp data hasil penelitian jumlah kesalahan mahasiswa dalam menyelesaikan soal cerita pada mata kuliah pembelajaran matematika SD digunakan teknik analisis persentase kesalahan mahasiswa pada tiap jenis kesalahan untuk tiap item diperoleh dengan cara jumlah kesalahan yang terjadi tiap jenis kesalahan pada tiap item dibagi dengan jumlah responden dikali seratus persen (Masrura, 2005).

$$
p=\frac{T_{i}}{T} \times 100 \%
$$

Keterangan:

$\mathrm{p}=$ persentase kesalahan pada item ke-i

$\mathrm{T}_{\mathrm{i}}=$ ju mlah kesalahan yang terjadi tiap jenis kesalahan pada item ke-i

$\mathrm{T}=$ ju mlah responden

Untuk menghitung persentase kesalahan, dihitung dari data jumlah kesalahan mahasiswa pada tiap jenis kesalahan untuk tiap item.

Tabel 1. Interval dan kategori tingkat kesalahan mahasiswa dalam menyelesaikan soal cerita pada mata kuliah pembelajaran matematika SD.(Nur Aly et al., 2019)

\begin{tabular}{|c|c|}
\hline Tingkat kesalahan & Kategori tingkat kesalahan \\
\hline $0 \%-10 \%$ & Sangat rendah \\
$11 \%-25 \%$ & Rendah \\
$26 \%-45 \%$ & Sedang \\
$46 \%-60 \%$ & Tinggi \\
$61 \%-100 \%$ & Sangat tinggi \\
\hline
\end{tabular}

\section{HASIL DAN PEMBAHASAN}

Hasil analisis ditampilkan berikut ini adalah hasil analisis persentase jenis kesalahan mahasiswa pada tiap item. Hasil pengolahan tersebut ditampilkan pada tabel berikut.

\section{Persentase jenis kesalahan mahasiswa pada tiap item.}

Tabel 2. Kategori tingkat kesalahan mahasiswa dalam menyelesaikan soal cerita pada mata kuliah pembelajaran matematika SD untuk item 1

\begin{tabular}{|c||c|c|c|}
\hline Jenis kesalahan & $\begin{array}{c}\text { Jumlah } \\
\text { kesalahan }\end{array}$ & $\begin{array}{c}\text { Persentase } \\
\text { kesalahan }\end{array}$ & $\begin{array}{l}\text { Kategori tingkat } \\
\text { kesalahan }\end{array}$ \\
\hline Kesalahan konsep (A) & 0 & 0 & Sangat rendah \\
\hline Kesalahan menggunakan data (B) & 2 & 5,40 & Sangat rendah \\
\hline Kesalahan interpretasi bahasa (C) & 0 & 0 & Sangat rendah \\
\hline Kesalahan algoritma (D) & 4 & 10,81 & Sangat rendah \\
\hline Kesalahan teknis (E) & 5 & 13,51 & Rendah \\
\hline
\end{tabular}


Berdasarkan tabel di atas dapat dikemukakan bahwa dari 37 orang mahasiswa persentase tiap jenis kesalahan item 1 diperoleh :

1. Persentase kesalahan konsep 0 , artinya $100 \%$ mahasiswa telah memahami konsep dengan baik

2. Persentase kesalahan menggunakan data 5,40, artinya $94,6 \%$ mahasiswa telah menggunakan data dengan benar.

3. Persentase kesalahan interpretasi bahasa 0, artinya 100\% mahasiswa telah menginterpretasikan bahasa dengan benar.

4. Persentase kesalahan algoritma 10,81, artinya mahasiswa $89,19 \%$ telah mengunakan algoritma dengan benar.

5. Persentase kesalahan teknis13,51, artinya 86,49\% mahasiswa tidak melakukan kesalahan teknis.

Tabel 3. Jenis, jumlah dan kategori tingkat kesalahan mahasiswa dalam menyelesaikan soal cerita pada mata kuliah pembelajaran matematika SD untuk item 2

\begin{tabular}{|c||c|c|c|}
\hline Jenis kesalahan & $\begin{array}{c}\text { Jumlah } \\
\text { kesalahan }\end{array}$ & $\begin{array}{c}\text { Persentase } \\
\text { kesalahan }\end{array}$ & $\begin{array}{l}\text { Kategori tingkat } \\
\text { kesalahan }\end{array}$ \\
\hline \hline Kesalahan konsep (A) & 0 & 0 & Sangat rendah \\
\hline Kesalahan menggunakan data (B) & 0 & 0 & Sangat rendah \\
\hline Kesalahan interpretasi bahasa (C) & 0 & 0 & Sangat rendah \\
\hline Kesalahan algoritma (D) & 6 & 16,21 & Rendah \\
\hline Kesalahan teknis (E) & 5 & 13,51 & Rendah \\
\hline
\end{tabular}

Sumber: Hasil Pengolaan Data

Berdasarkan tabel di atas dapat dikemukakan bahwa dari 37 orang mahasiswa persentase tiap jenis kesalahan item 2 diperoleh :

1. Persentase kesalahan konsep 0, artinya $100 \%$ mahasiswa telah memahami konsep dengan baik

2. Persentase kesalahan menggunakan data 0 artinya $100 \%$ mahasiswa telah menggunakan data dengan benar.

3. Persentase kesalahan interpretasi bahasa 0 , artinya $100 \%$ mahasiswa telah menginterpretasikan bahasa dengan benar.

4. Persentase kesalahan algoritma 16,21, artinya $83,79 \%$ mahasiswa telah menggunakan algoritma dengan benar.

5. Persentase kesalahan teknis 13,51 , artinya $86,49 \%$ mahasiswa tidak melakukan kesalahan teknis.

Tabel 4. Jenis dan jumlah kategori tingkat kesalahan mahasiswa dalam menyelesaikan soal cerita pada mata kuliah pembelajaran matematika SDuntuk item 3:

\begin{tabular}{|c|c|c|c|}
\hline Jenis kesalahan & $\begin{array}{c}\text { Jumlah } \\
\text { kesalahan }\end{array}$ & $\begin{array}{c}\text { Persentase } \\
\text { kesalahan }\end{array}$ & $\begin{array}{l}\text { Kategori tingkat } \\
\text { kesalahan }\end{array}$ \\
\hline Kesalahan konsep (A) & 11 & 29,72 & Sedang \\
\hline Kesalahan menggunakan data (B) & 0 & 0 & Sangat rendah \\
\hline Kesalahan interpretasi bahasa (C) & 5 & 13,51 & Rendah \\
\hline Kesalahan algoritma (D) & 11 & 29,72 & Sedang \\
\hline Kesalahan teknis (E) & 7 & 18,91 & Rendah \\
\hline
\end{tabular}


Berdasarkan tabel di atas dapat dikemukakan bahwa dari 37 orang mahasiswa persentase tiap jenis kesalahan item 3 diperoleh :

1. Persentase kesalahan konsep 29,72 , artinya $70,28 \%$ mahasiswa telah memahami konsep dengan baik

2. Persentase kesalahan menggunakan data 0 artinya $100 \%$ mahasiswa telah menggunakan data dengan benar.

3. Persentase kesalahan interpretasi bahasa 13,51 , artinya $86,49 \%$ mahasiswa telah menginterpretasikan bahasa dengan benar.

4. Persentase kesalahan algoritma 16,21 , artinya $83,79 \%$ mahasiswa telah menggunakan algoritma dengan benar.

5. Persentase kesalahan teknis 13,51 , artinya $86,49 \%$ mahasiswa tidak melakukan kesalahan teknis.

Tabel 5. Jenis, jumlah dan kategori tingkat kesalahan mahasiswa dalam menyelesaikan soal cerita pada mata kuliah pembelajaran matematika SD untuk item 4:

\begin{tabular}{|c||c|c|c|}
\hline Jenis kesalahan & $\begin{array}{c}\text { Jumlah } \\
\text { kesalahan }\end{array}$ & $\begin{array}{c}\text { Persentase } \\
\text { kesalahan }\end{array}$ & $\begin{array}{l}\text { Kategori tingkat } \\
\text { kesalahan }\end{array}$ \\
\hline \hline Kesalahan konsep (A) & 1 & 2,70 & Sangat rendah \\
\hline Kesalahan menggunakan data (B) & 0 & 0 & Sangat rendah \\
\hline Kesalahan interpretasi bahasa (C) & 7 & 18,91 & Rendah \\
\hline Kesalahan algoritma (D) & 8 & 21,62 & Rendah \\
\hline Kesalahan teknis (E) & 7 & 18,91 & Rendah \\
\hline
\end{tabular}

Berdasarkan tabeln di atas ndapat dikemukakan nbahwa dari 37 norang mahasiswa persentase tiap jenis kesalahan item 4 diperoleh :

1. Persentase kesalahan konsep 2,70 artinya 97,3\% mahasiswa telah memahami konsep dengan baik

2. Persentase kesalahan menggunakan data 0 artinya $100 \%$ mahasiswa telah menggunakan data dengan benar.

3. Persentase kesalahan interpretasi bahasa 18,91, artinya 81,09\% mahasiswa telah menginterpretasikan bahasa dengan benar.

4. Persentase kesalahan algoritma 21,62, artinya 78,38\% mahasiswa telah menggunakan algoritma dengan benar.

5. Persentase kesalahan teknis 18,91, artinya $81,09 \%$ mahasiswa tidak melakukan kesalahan teknis.

Tabel 6. Jenis, jumlah dan kategori tingkat kesalahan mahasiswa dalam menyelesaikan soal cerita pada mata kuliah pembelajaran matematika SD untuk item 5:

\begin{tabular}{|c||c||c|c|}
\hline Jenis kesalahan & $\begin{array}{c}\text { Jumlah } \\
\text { kesalahan }\end{array}$ & $\begin{array}{c}\text { Persentase } \\
\text { kesalahan }\end{array}$ & $\begin{array}{l}\text { Kategori tingkat } \\
\text { kesalahan }\end{array}$ \\
\hline Kesalahan konsep (A) & 14 & 37,83 & Sedang \\
\hline Kesalahan menggunakan data (B) & 10 & 27,02 & Sedang \\
\hline Kesalahan interpretasi bahasa (C) & 5 & 13,51 & Rendah \\
\hline Kesalahan algoritma (D) & 7 & 18,91 & Rendah \\
\hline Kesalahan teknis (E) & 0 & 0 & Sangat rendah \\
\hline
\end{tabular}


Berdasarkan tabel di atas dapat dikemukakan bahwa dari 37 orang mahasiswa persentase tiap jenis kesalahan item 5 diperoleh :

1. Persentase kesalahan konsep 37,83 artinya $62,17 \%$ mahasiswa telah memahami konsep dengan baik

2. Persentase kesalahan menggunakan data 27,02 artinya $72,98 \%$ mahasiswa telah menggunakan data dengan benar.

3. Persentase kesalahan interpretasi bahasa 13,51 , artinya $86,49 \%$ mahasiswa telah menginterpretasikan bahasa dengan benar.

4. Persentase kesalahan algoritma 18,91 artinya $81,09 \%$ mahasiswa telah menggunakan algoritma dengan benar.

5. Persentase kesalahan teknis 0 , artinya $100 \%$ mahasiswa tidak melakukan kesalahan teknis.

\section{Pembahasan Hasil Penelitian}

Berdasarkan pembahasan hasil analisis diperoleh bahwa untuk persentase jenis kesalahan yang paling banyak dilakukan oleh mahasiswa pada tiap item:

1. Dari data pada tabel 2 diperoleh persentase kesalahan yang paling tinggi dari kelima jenis kesalahan pada item 1 adalah kesalahan teknis dengan persentase kesalahan 13,51\%, kategori tingkat kesalahan rendah dengan demikian dapat dikatakan bahwa dari 37 mahasiswa hanya 86,49\% yang tidak melakukan kesalahan teknis.

2. Dari data pada tabel 3 diperoleh persentase kesalahan yang paling tinggi dari kelima jenis kesalahan pada item 2 adalah kesalahan algoritma dengan persentase kesalahan 16,21\%, kategori tingkat kesalahan rendah dengan demikian dapat dikatakan bahwa dari 37 mahasiswa hanya 83,79\% yang tidak melakukan kesalahan algoritma.

3. Dari data pada tabel 4 diperoleh persentase kesalahan yang dilakukan mahasiswa untuk jenis kesalahan konsep dan kesalahan algoritma adalah sama yaitu $29,72 \%$ data ini merupakan data tertinggi dari semua data pada item ini, sehingga pada item ini dapat dikatakan bahwa pencapaian tingkat kesalahan terbesar berada pada dua jenis kesalahan dari data diperoleh bahwa dari 37 mahasiswa yang tidak melakukan kesalahan dari kedua jenis kesalahan tersebut hanya $70,28 \%$.

4. Dari data pada tabel 5 diperoleh persentase kesalahan yang paling tinggi dari kelima jenis kesalahan pada item 4 tersebut adalah kesalahan algoritma dengan persentase kesalahan adalah 21,62\% kategori tingkat kesalahan rendah dengan demikian dapat dikatakan dari 37 mahasiswa hanya 78,38\% yang tidak melakukan kesalahan algoritma.

5. Dari data pada tabel 6 diperoleh persentase kesalahan yang paling tinggi dari kelima jenis kesalahan pada item 5 adalah kesalahan konsep dengan persentase kesalahan 37,83\% kategori tingkat kesalahan sedang dengan demikian dapat dikatakan bahwa dari 37 mahasiswa hanya $62,17 \%$ yang menguasai konsep.

Berdasarkan jenis kesalahan yang dilakukan mahasiswa diperoleh bahwa kesalahan terjadi karena:

a. Kesalahan konsep

Kesalahan tersebut terjadi karena pada umumnya mahasiswa belum memahami konsep dasar materi soal cerita persamaan kuadrat. Hal ini jelas terlihat 
pada jawaban responden yang pada umumnya tidak menjawab soal sampai tuntas, artinya terdapat beberapa soal yang sama sekali tidak dikerjakan sehingga disimpulkan bahwa responden belum memahami konsep dengan jelas.

b. Kesalahan menggunakan data

Kesalahan menggunakan data dapat terlihat dengan jelas dari jawaban responden. Kesalahan menggunakan data yang dimaksud di sini adalah memuat data yang seharusnya tidak digunakan atau tidak memuat data yang seharusnya digunakan atau memasukkan data ke dalam rumus secara keliru walaupun rumus yang digunakan sudah tepat.

c. Kesalahan interpretasi bahasa

Kesalahan interpretasi bahasa terlihat dengan jelas dari jawaban responden yaitu tidak mampu menerjemahkan bahasa sehari-hari ke dalam bentuk matematika. Hal ini berakibat pada ketidakmampuan mahasiswa untuk dapat melakukan penjabaran penyelesaian soal secara matematis.

d. Kesalahan algoritma

Kesalahan algoritma terlihat dengan jelas pada jawaban responden yaitu ketidakhirarkisan responden dalam mnyelesaikan soal cerita persamaan kuadrat.terdapat sejumlah jawaban responden yang tidak menuliskan kesimpulan akhir dari npenyelesaian soal-soal tersebut. terdapat pula jawaban beberapa responden yang tidak mengikuti langkah-langkah penyelesaian soal sesuai yang diharapkan, tetapi responden pada umumnya langsung mencamtumkan langkahlangkah sehingga hasil akhir tersebut dapat pula diperoleh.

e. Kesalahan teknis

Kesalahan teknis terlihat dengan jelas dari jawaban responden dalam menyelsaikan soal cerita persamaan kuadrat. Rata-rata responden melakukan kesalahan operasi aljabar dan juga kesalahan hitung.

Data yang diperoleh dari penelitian ini menunjukkan perlunya mahasiswa mendapat perhatian dari semua pihak yang terkait demi tercapainya pencapaian tujuan pembelajaran yang maksimal. Memperhatikan hasil penelitian, penulis memperkirakan bahwa kemungkinan yang menjadi penyebab dterjadinya kesalahan yang dilakukan mahasiswa adalah kurangnya kehatian-hatian dalam menjawab soal. Selain itu juga karena adanya sikap sebahagian mahasiswa yang hanya mengandalkan kemampuan dosen dalam menyampaikan materi, sehingga mahasiswa tidak mempunyai kreatifitas belajar serta tidak ada keingintahuan untuk menumbuhkan dan selanjutnya memantapkan kemampuan belajar mandiri.

\section{Diskusi}

Penelitian ini mengungkapan beberapa masalah yang mebutuhkan sulusi dalam menyelesaikan masalah tersebut, berikut ini beberapa suslusi yang peneliti tawarkan,

\section{Pengajaran Remedial}

Dalam merencanakan dan menyiapkan program remedi, dosen harus bersedia dmenyisihkan waktu untuk melihat semua faktor yang mungkin mempengaruhi pencapaian mahasiswa dalam belajar matematika, termasuk tiap sikap dan minat. Jadi dalam hal ini sangat diperlukan ketekunan dan keikhlasan dosen ddalamn dmemantau dkelemahan mahasiswa dtersebut (Hikmasari \& Mariani, n.d.). 
Ada dua hal yang perlu diperhatikan dalam pengajaran pelaksanaan program remedi, yaitu: Pengajaran individual dan Pengajaran kelompok. Untuk pengajaran individual, pertama-tama dosen harus memberikantes diagnostik kepada masingmasing peserta didik untuk mengetahui kekurangan-kekurangan yang bersifat individual dan bidang-bidang yang mendapat penanganan khusus, selanjutnya diadakan wawancara untuk mengetahui kelemahan mahasiswa tersebut secara mendalam setelah itu, pengajaran remedi dapat dilakukan, dalam hal ini untuk setiap kesalahan yang ditemukan, disiapkan suatu pekerjaan kolektif yang bersifat individual.

Untuk mengetahui kemampuan mahasiswa, hendaknya selalu diberikan tes pada setiap akhir pertemuan dengan hanya memerlukan waktu sepuluh sampai lima belas menit, Sedangkan untuk pengajaran kelompok, dilaksanakan apabila dalam kelompok kecil atau besar mempunyai kelemahan yang hampir sama dalam suatu kelompok tertentu.

Pengajaran remedi diarahkan untuk pencapaian hasil belajar secara optimal sesuai kemampuan masing-masing mahasiswa melalui perbaikan-perbaikan secara keseluruhan dalam hal belajar mengajar.

\section{Bimbingan di luar kelas}

Bimbingan dapat dilakukan dengan memberi kesempatan kepada mahasiswa untuk berkonsultasi sehubungan dengan kesulitan-kesulitan yang dihadapi dalam pengajaran matematika di dalam kelas. Mahasiswa diberi kesempatan untuk menanyakan hal-hal yang dianggap sulit dan materi-materi prasyarat yang belum dipahaminya. (Yunita, 2020)

Di dalam bimbingan belajar seorang dapat juga menjelaskan cara-cara belajar yang efesien dan efektif serta menentukan pembagian waktu dalam perncanaan jadwal belajarnya sebab belajar dengan penuh disiplin dan teratur akan dapat meningkatkan prestasi belajar seorang mahasiswa yang mengatur waktunya dalam belajar dapat mencegah keraguan mahasiswa mengenai apa yang akan dipelajari dan dikerjakan, serta memungkinkan untuk mempelajari dengan tepat pada waktu yang tepat pula. Penempatan waktu untuk mengulangi kembali pelajaran matematika di rumah dapat diatur berdasarkan proporsinya terhadap mata kuliah yang lain, sehingga benar-benar terjamin situasi belajar yang sistamatis.

Selanjutnya bimbingan pengajaran di luar kelas bukan hanya dilakukan oleh pihak dosen, melainkan juga oleh pihak mahasiswa itu sendiri. Dengan bimbingan pengajaran di luar kelas diharapkan akan dapat memberikan kemudahan bagi mahasiswa.

\section{Belajar Kelompok}

Belajar kelompok itu mempunyai keuntungan-keuntungan sosial. Belajar kelompok dapat dmenekankan suatu interaksi dalam arti saling membantu, berkomunikasi, berdiskusi, membagi tugas, menerima tanggung jawab dan mengembangkan sikap saling menghargai teman serta pekerjaannya. Namun yang sangat perlu diperhatikan dalam kegiatan belajar kelompok adalah efesiensi dan kefektifan. Belajar kelompok sangat ditentukan pula oleh banyaknya anggota kelompok. Sebagaimana Jafar Masuha. (Meditamar et al., 2017), memberikan petunjuk bahwa kelompok yang paling efektif adalah kelompok yang beranggotakan antar dua sampai enam orang lebih dari itu akan timbul persaingan yang tidak sehat. 


\section{KESIMPULAN}

Dari hasil penelitian yang telah diuraikan sebelumnya, maka dapat ditarik kesimpulan bahwa persentase kesalahan yang dilakukan mahasiswa PGSD untuk. tiap jenis kesalahan dari 37 mahasiswa yang paling banyak pada item diperoleh: item 1 kesalahan teknis. 13,51\%, artinya 86,49\% tidak melakukan kesalahan teknis, item 2 kesalahan algoritma 16,21\%, artinya 83,79\% tidak melakukan kesalahan algoritma, item 3 kesalahan konsep dan algoritma besarnya sama 29,72\%, artinya 70,28\% mahasiswa tidak melakukan kesalahan konsep dan algoritma, item 4 kesalahan algoritma 21,62\%, artinya 78,38\% mahasiswa tidak melakukan. kesalahan algoritma, item 5 kesalahan konsep 37,83\%, artinya hanya 62,17\% mahasiswa yang menguasai konsep.

\section{DAFTAR PUSTAKA}

Chapra, Stevenp, dan Canale, Raymon pertanian, (1989). Metode Numerik. Jakarta: Erlangga

Depdikbud, (1993). Evaluasi dan Penilaian Jakarta. Proyek Peningkatann Mutu Guru Dirjen. DIKDASMEN.

Djaali. (1990). Pengaruh Kemampuan Guru Terhadap Prestasi Belajar Matematika pada Sekolah Menengah Pertama di Sulawesi Selatan. Laporan Hasil Penelitian Ujung Pandang: P4M Dirjen Dikti.

Hudoyo, Herman. (1990). Strategi Mengajar Belajar Matematika. Malang: IKIP Malang.

Hikmasari, P., \& Mariani, S. (n.d.). Analisis Hasil Asesmen Diagnostik dan Pengajaran Remedial pada Pencapaian Kemampuan Pemecahan Masalah Matematika melalui Model Problem Based Learning.

Kolins, A. Y., Wahyuningsih, W., Safrudin, N., \& Rusdin, M. E. (2020). Analisis Kesalahan Peserta Didik dalam Menyelesaikan Soal Matematika pada Fungsi Komposisi dan Fungsi Invers. AlphaMath: Journal of Mathematics Education, 6(2), 86. https://doi.org/10.30595/alphamath.v6i2.7866

Meditamar, M. O., Gunawan, R. G., \& Oktafia, M. (2017). Pengaruh Strategi Belajar Murder Dengan Setting Belajar Kelompok Terhadap Kemampuan Pemecahan Masalah Matematika Siswa SMP Negeri 1 KerincI. 13(01), 11

Nur Aly, B. F., Sujadi, A. A., \& Taufiq, I. (2019). Analisis Kesalahan dalam Menyelesaikan Soal Matematika pada Siswa Kelas X SMK Negeri 1

Yunita, D. (2020). Pengaruh Pembelajaran Luar Kelas dengan Teknik Scaffolding Terhadap Kemampuan Komunikasi Matematis Siswa. 05(01), 15Seyegan. UNION: Jurnal Ilmiah Pendidikan Matematika, 7(1), 135. https://doi.org/10.30738/union.v7i1.4050

Masrura, (2005). Profil kesalahan menyelesaikan nsoal matematika pada pokok nbahasan persamaan ndan pertidaksamaan nkuadrat mahasiswa nkelas X SMA Negeri 1 Anggeraja Kab Enrekang. Skripsi Tidak diterbitkan. FMIPA UNM. 
Muhkal, M, (1999). Menumbuhkan Kemampuan menyelesaikan masalah melalui proses Belajar Mengajar, Eksponen: Jurnal Matematika dan Pendidikan Matematika. FMIPA IKIP Ujung Pandang.

Noor Madiri. B. K. (2004). Matematika SMA Untuk Kelas X. Jakarta: Erlangga.

Rohani. (2000). Profil Kesalahan Mahasiswa Kelas I Dalam Menyelesaikan SoalSoal Persamaan Kuadrat Pada SMU Neg I Sinjai Timur Kabupaten Sinjai. Skripsi. Ujung Pandang: FMIPA UNM.

Russefendi E, T. (1988). Pengembangan Kepada Membantu Guru Mengembangkan Kompetensinya Dalam Pengajaran Matematika untuk Meningkatkan CBSA. Bandung: Tarsito.

Sirajuddin. (2005). Matematika $\quad$ Versi $\quad$ Sirajuddin. http://www.depdiknas.90.idi/Jurnal/45/

Slameto. (1991). Belajar dan Faktor-Faktor yang Mempengaruhinya. Jakarta: Rineka Cipta.

Suhaemi, (2000). Identifikasi Kesalahan Dalam Menyelesaikan Masalah Persamaan Dan Pertidaksamaan Linear Dengan Satu Variabel Pada Mahasiswa Kelas 1 SLTP Negeri 3 Makassar. Skripsi. Ujung Pandang: FMIPA UNM.

Suherman, E. (2004). Strategi Pembelajaran Matematika Kontemporer. Bandung: Universitas Pendidikan Indonesia.

Thalib, Ahmad. (1995). Laboratorium Matematika. Jurnal Pendidikan dan Keguruan No. 2 Juli. IKIP. Ujung Pandang.

Tiro, M. Arif, (2000). Dasar-dasar Statistika. Makassar State University Press. Makassar.

Wahid, Abdul, (2003). Deskripsi Kemampuan Menyelesaikan Soal Cerita Matematika Mahasiswa Kelas IV SD Negeri No. 4 Maddukelleng Kabupaten Wajo. Skripsi Tidak diterbitkan. FMIPA UNM Makassar. 